\title{
INVESTIGATION OF ACTIVATED CARBON PRODUCED FROM SUGARCANE BAGASSE AND ITS APPLICATIONS ON SEWAGE WATER TREATMENT
} *Sasy A.H.B. ; *Soha R.A. Khalil and Abdel Wahab M. Mahmoud** *Sugar Technol., Res. Dept., Sugar Crops Res. Inst., Research. Center, Giza, Egypt

**Plant physiol., Dept., Faculty of Agriculture, Cairo University, Giza, Egypt

Keyword: Sugar cane bagasse, Active carbon, Sewage water treatment.

\section{ABSTRACT}

Activation phase was used to produce activated carbon (AC) from sugar cane bagasse (SCB). Whereas, the activation was done by two ways; the first way had crashed granulate AC to fine powder (PAC) and the second was the synthesis process nano-particles from granulate activated carbon (NAC). The surface area of PAC has been estimated by Brunauer-EmmettTeller (BET) and characterization of NAC by using Transform Infrared spectrum (FTIR) and Trasmission Electron Microscope (TEM).

The efficient adsorbent effects for each products and natural lime stone were tested by its application on sewage water to improve its physiochemical properties which included (pH, TSS, COD, BOD, TDS, ASR, NO3, PO4, Mg, Ca, Na, Cd, Cu, Fe and Ni) through different soaking period $(0,10,15$ and 20 day).

The results cleared that the effects of using individually nano activate carbon was more efficient than PAC and natural lime stone to purified sewage water treatment with 10 days soaking period compared to other soaking periods. Furthermore, NAC exhibited the high efficiency absorbent to remove metal ions (NO3, PO4, $\mathrm{Mg}, \mathrm{Ca}$ and $\mathrm{Na}$ ) and heavy metals ion $(\mathrm{Cu}, \mathrm{Cd}, \mathrm{Fe}$ and $\mathrm{Ni})$ and decrement $\mathrm{BOD}$ and $\mathrm{COD}$ from sewage water. So that, it was selected to test its effects in combination with lime stone on sewage water treatment.

Based on the obtained data the corresponding reduction values for all studied traits were higher as compared to applying each of them separately through soaking period 10 days.

It can be recommended that the combination of (NAC + limestone) are a very good material in the field of sewage water treatment before recycle it, which can be apply for reducing some pollutants in sewage water after disposable.

\section{INTRODUCTION}

Nowadays disposal of agriculture more tend to environmental friendly solutions by transforming the unwanted waste to valuable materials and thus, improves and upgrades the technology Hu (2018). AC used in diverse shapes such as powder, granular, pellet and activated carbon fiber. These types have its specific application Guo et al. (2003). The production of AC around the world is estimated to be around 100000 ton annually (Ajinomoh 
and Salahudeen (2014). Today, much effort has been devoted to exploiting waste as raw materials in activated carbon production. The pore size of activated carbon can be divided into three categories: the pore size is smaller than $2 \mathrm{~nm}$, the pore size is mesoporous in $2-50 \mathrm{~nm}$, and the pore size is larger than that in $50 \mathrm{~nm}$ (Changjia et al., 2019). Generally, AC can be prepared from a large number of low-cost sources and agricultural residues i.e corn cob, apricot stone, rice husk and cane bagasse, date palm residue Nayl et al. (2017). The main reason for the strong adsorption ability and adsorption capacity of activated carbon is total surface area in its structure which generally as high as $500-1700 \mathrm{~m}^{2 /} / \mathrm{g}$ and small micropores compared with other adsorption materials (radius $<0.02 \mathrm{~nm}$ ) Bao et.al., (2011). The pore purview distribution of activated carbon is very wide, ranging from 1 nm to thousands of nm (Liu et al ., 2012) whereas, (Tancredi et al., 2004) reported that Powdered activated carbon (PAC), compared to granular activated carbon because it has a much faster adsorption rate and a larger adsorption capacity of various organics usually related to their much higher surface area, pore volume and porosity.

Nowadays nanotechnology has expanded broadly in all science themes. The nanotechnology is one of the new technologies that entered almost all sides of our lives and were used in agriculture production (Husen and Siddiqi, 2014). Many nano-sized materials (metal oxide, zeolites, carbon-based nanoparticle, nano-clays and nanocomposites) have been used as adsorbent to remove heavy metal ions from wastewater (Zhao et al., 2011 and Hua et al. 2012). The nature of activated carbon surfaces especially the nano size ones have made them promising adsorbents to remove heavy metals from industrial wastewater but they are restricted in use due to their high cost Kumar and Chawla (2014) and El-kady et al., (2015).

Actived carbon which is used in any application must have adequate adsorptive capacity, chemical purity and mechanical strength. Furthermore, all these specifications should coexist with a low production cost. The chemical structure of AC could preferentially adsorb organic materials and other non-polar compounds from the gas or liquid streams. Due to these properties, they have been used for removal of COD and BOD, heavy metals removal, and solutions decolorization (Nayl et al., 2017, Saleh et al., 2015 and Changjia et al., (2019).

Wastewater purification is usually achieved through adsorption on soil, plant uptake, sedimentation, and filtration, microbial and chemical decomposition. Also, wastewater purification could be achieved by the modification in hydraulic loading rate, hydraulic retention time, water depth, and recycling system of crud water. However, to achieve better performance, some highly reactive chemical materials are also being used as a substrate in wastewater purification such as lime stone, shale, activated 
carbon, zeolite and fly ash (Vohla et al.. 2011; Nayl et al., 2017, , Almuktar et al., 2018, Changjia et al., (2019).

Limestones are rocks predominantly originated from calcite minerals (calcium carbonate with trigonal structure, $\mathrm{CaCO}_{3}$ ). They are solid and grained sedimentary rocks of organic or chemical origin contain more than $95 \% \mathrm{CaCO}_{3}$. Aziz et al., (2001) found that calcium carbonate $\left(\mathrm{CaCO}_{3}\right)$ was an effective material to purified water contaminated with heavy metal ions. Sdiri et al. (2012) reported that lime stone contains stains (silica, iron or aluminum oxide and different clay minerals) that enhanced sorption capacity. Also, Ahmad et al. (2012) recorded a remarkable efficiency of calcium carbonate as adsorbent (90\%) that significantly remove heavy metal ions from drinking water.

According to the World Health Organization (WHO), the most immediate concern and abundant metals are cadmium, chromium, copper, lead, nickel, and zinc. Copper is an essential micronutrient to the plants but at higher concentrations it may become toxic. Heavy metal contamination exists in aqueous waste streams of many industries, such as metal plating facilities, mining operation and tanneries. Therefore, mitigated the hazardous effect of heavy metals on the ecosystem is very important (Rai, 2009).

The current work aims to produce activated carbon (AC) material by two methods; the first is powder (PAC) and the second is the synthesis process nanoparticles from sugar cane bagasse (NAC). In addition, assess the effects of these methods on the physical properties of the AC as well as their application to the disposal of sewage water.

\section{MATERIALS:}

\section{MATERIALS AND METHODS}

\section{Raw material}

1. Sugar cane bagasse was obtained from pilot milling of Sugar Crops Research Institute, Agriculture Research Center, Giza Agriculture Research Station, Egypt.

2. Limestone was purchased from El-Ahram Company for Mining and Natural Fertilizers, Giza, Egypt

3. Sewage water was obtained from Egyptian station of sewage water collection Co., El-Safe, Giza, Egypt. The chemical compositions of sewage water sample were represented in Table 1.

Table1: Chemical compositions of sewage water at zero time

\begin{tabular}{|c|c|c|c|c|c|c|c|c|c|c|c|c|c|c|}
\hline \multirow[t]{2}{*}{ pH } & \multirow[t]{2}{*}{ SAR } & COD & BOD & TSS & TDS & $\mathrm{PO}_{4}$ & $\mathrm{NO}_{3}$ & $\mathrm{Ca}$ & Mg & $\mathbf{N a}$ & $\mathbf{C u}$ & Cd & $\mathbf{F e}$ & $\mathbf{N i}$ \\
\hline & & \multicolumn{2}{|c|}{$\mathrm{mg} \mathrm{O}_{2} / \mathrm{L}$} & \multicolumn{8}{|c|}{$\mathrm{mg} / \mathrm{L}$} & \multicolumn{3}{|c|}{$\mu \mathrm{g} / \mathrm{L}$} \\
\hline 7.4 & 15.4 & 92.3 & 63.6 & 377 & 12.4 & 2.41 & 0.65 & 38.4 & 14.8 & 58.6 & 17.6 & 13.6 & 306.2 & 45.7 \\
\hline
\end{tabular}

SAR: sodium adsorption ratio, COD: chemical oxygen demand, BOD: biological oxygen demand,TSS: total soluble solids, TDS: total dissolved solids 


\section{METHODS:}

\section{Raw materials preparation:}

Bagasse as a by-product of the commercial sugarcane cultivar (GT. 54-9) was tested. The sample of 40 millable cane stalks was squeezed by an electric pilot mill belongs to Sugar Crops Research Institute, Agriculture Research Center, Giza Agriculture Research Station, Egypt. Wet bagasse was collected and washed with tap water to remove any debris then sun drying for three days and put in oven at $110^{\circ} \mathrm{C}$ till constant weight. The dried bagasse was milled to be in a form of powders.

\section{Activation phase:}

Activation phase carried out according to the method described by Ajinomoh and Salahudeen (2014). The raw materials were impregnated in phosphoric acid $(50 \% \mathrm{v} / \mathrm{v})$ as an activating agent by 1:1 ratio (bagasse to acid) for $24 \mathrm{hr}$ to cover the whole mass and to give a paste of soft consistency. The impregnated sample was admitted into a muffle furnace at $500^{\circ} \mathrm{C}$ for $3 \mathrm{hr}$. The obtained granular carbonized mass was left to cool and washed many time with hot distilled water pass through litmus paper to remove washing water. The presence of phosphate was recognized in the acid treated sample by the white precipitate of $\mathrm{Pb}_{3}\left(\mathrm{PO}_{4}\right)_{2}$. The AC's product was dried at $105^{\circ} \mathrm{C}$ in an air oven. Active carbons product (PAC) are milled to pass through a 50-mesh sieve $(0.297 \mathrm{~mm})$ then it was stored in polyethylene bags for subsequent characterization and adsorption studies.

\section{Synthesis of bagasse activated carbon nanoparticles:}

Synthesis of bagasse ignoc carbon nanoparticles (powder) was done using the method of up to bottom molecular physical and chemical approach under $2 \mathrm{Mpa}$ pressure. The raw material of bagasse active carbons was grinding continually for 18 hours then soaking in mixed solution of $\mathrm{HCl}: \mathrm{NaOH}$ : hexametaphosphate in the ratio of $(1: 1: 2)$ under vigorous stirring. The stirring was continued for $12 \mathrm{~h}$. then $3 \mathrm{ml}$ of Tubercidin tridecyl ecosenoin oxolamine serine methyl ester (TEOS) solution was add. The resulted material was filtered then exposed to $120^{\circ} \mathrm{C}$ constantly for 24 hours, after that it left under pressure ( $2 \mathrm{Mpa}$ ) for terminated 36 hours; finally ultrasonic was done for 30 minutes to separate nano particles aggregation. The size and shape of bagasse AC nanoparticles were observed directly by Transmission Electron Microscopy (TEM) using an electron acceleration voltage of $60 \mathrm{kV}$. Transform Infrared spectrum (FTIR - 8400 S Shimadzu, Japan) was used 
to determine the change chemical structural of functional groups in NAC has preparation.

\section{Experimental}

16 treatments were carried out on sewage water as follows:

1- $\quad$ Bagasse active carbon $6 \mathrm{~g} / \mathrm{l}$.

2- $\quad$ Lime stone $6 \mathrm{~g} / \mathrm{l}$.

3- Nano bagasse active carbon $0.5 \mathrm{mg} / \mathrm{l}$

4- $\quad 0.5 \mathrm{mg} / \mathrm{l}$ Nano bagasse active carbon $+6 \mathrm{~g} / \mathrm{l}$ lime stone.

Each treatment was applied at four soaking periods with sample of sewage water (zero, 10, 15 and 20 days) according to Saleh et al., (2015).

\section{Evaluation tests}

- Moisture, total carbohydrate, crud fiber, crud protein of raw bagasse were determined according to (A.O.A.C 2010).

- The chemical constituents of raw bagasse, bagasse active carbon and lime stone were determined by using Atomic Absorption Spectrophotometer method (Helrich, 1990).

- Using Multipoint (BET) Brunauer-Emmett-Teller to measurements Surface area which performed to get an overview of the porous characteristics of the activated sample included (surface area, pores volume, and pore size distribution). Nitrogen adsorption isotherm $\left(\mathrm{N}_{2}\right)$ was produced at $77 \mathrm{~K}$ for this purpose using Surface Area Analyzer equipment, BEL-Sorb Max., made in Japan.

- Moreover Transmission Electron Microscopy (TEM) for granular (GAC), powder (PAC) and limestone were used to study the structural features of the carbon surface.

- Several laboratory experiments were carried out to select the optimal dosage for NAC which ended up to $0.5 \mathrm{mg} / \mathrm{l}$ sewage water is the most appropriate as dried powder. The whole experiment was repeated 3 times with the same periods during 2020, the average data were analyzed using ANOVA at 5\% significance level, the difference between treatments then analyzed using DMRT (Duncan Multiple Range Test) at $5 \%$.

- After each soaking period, samples of sewage water were taken to determine some chemical composition which were (pH, TSS, COD, BOD, ASR, Po4, No3, Mg, Ca, Na, Cd, Cu, Fe and Ni) according to (Helrich, 1990). Sorption studies were conducted in routine manner and adsorption experiments were carried out under room temperature conditions. The standardization dose of adsorbant, agitation time and period of contact with solution were recorded. 


\section{RESULTS AND DISCUSSION}

The chemical analysis of row dry bagasse, bagasse active carbon and lime stone are presented in Table (2). The results showed that sulpher and nitrogen are inferior in raw bagasse than both bagasse active carbon and lime stone. Data observed that hydrogen ratios are rich in raw dry bagasse than the other materials. Meanwhile, active carbon product was highest in carbon contents than the two other materials. The contents of carbon in case of all carbon groups are in the range of $48.9-50.49 \%$ and are much lower than those in the starting polymers of lignocelluloses materials. Similar relation is observed for nitrogen contents. Oxygen element is presented in the structure of analyzed materials whereas; in the case of polymeric precursor it occurs as a constituent of carbonyl group of the bagasse polymer. This element is also presented in the carbons structure in the form of carbonyl, carboxylic, lactonic, phenolic which can be formed during carbonization and activation processes. In the case of bagasse carbons not only oxygen but also $\mathrm{OH}$ groups coming from the residues of lignocelluloses structures. These results are in agreement with those mentioned by Changjia et al., (2019) who reported that in the preparation of activated carbon, the border chemical bond of the aromatic sheet which formed during shatter stage in carbonization process to form a border carbon atom with unpaired electrons.

These peripheral carbon atoms have unsaturated chemical bonds which can be reacting with heterocyclic atoms such as nitrogen, hydrogen, oxygen and sulfur to form different surface groups. Chemical constituents of lime stone were about $55.51 \% \mathrm{CaO}$ and ignition loss ratio $42.25 \%$.This results confirmed mineralogical proportion of calcite as well as element oxides is the major source of oxygen while $\mathrm{Ca}_{2} \mathrm{CO}_{3}$ is the main source for carbons content in lime stone structure. These results are in line with those obtained by Aziz et al., (2001).

Table 2: Chemical composition of sugar cane bagasse, bagasse activate carbon and limestone

\begin{tabular}{|c|c|c|c|c|c|c|c|c|c|c|c|}
\hline Material & $\begin{array}{c}\text { Mois } \\
\% \\
\end{array}$ & pH & $\begin{array}{c}\text { T.C } \\
\% \\
\end{array}$ & $\begin{array}{c}\text { C.F } \\
\% \\
\end{array}$ & $\begin{array}{c}\text { C.P } \\
\% \\
\end{array}$ & & & $\begin{array}{l}\mathrm{C} \\
\% \\
\end{array}$ & $\begin{array}{l}\mathrm{N}_{2} \\
\%\end{array}$ & $\begin{array}{c}\mathrm{H}_{2} \\
\% \\
\end{array}$ & $\begin{array}{l}\mathrm{S} \\
\% \\
\end{array}$ \\
\hline Row dry bagasse & 8.83 & - & 56 & 40 & 2.56 & & & 48.9 & 0.6 & 5.2 & 0.215 \\
\hline $\begin{array}{l}\text { Bagasse active } \\
\text { carbon }\end{array}$ & & 5.6 & & - & & & & 50.49 & 0.8 & 0.76 & 0.532 \\
\hline \multirow{3}{*}{$\begin{array}{l}\text { Lime stone } \\
\text { chemical } \\
\text { constituents \% }\end{array}$} & \multicolumn{2}{|c|}{$\mathrm{SiO}_{2}$} & $\mathrm{CaO}$ & $\mathbf{A l}_{2} \mathbf{C}$ & \multicolumn{2}{|c|}{$\mathrm{Fe}_{2} \mathrm{O}_{3}$} & & $\mathrm{So}_{3}$ & MgO & $\mathrm{Na2O}$ & K2O \\
\hline & 0.4 & & 55.51 & 0.2 & \multicolumn{2}{|c|}{0.22} & & .20 & 0.15 & 0.42 & 0.60 \\
\hline & \multicolumn{4}{|c|}{$\begin{array}{c}\text { Loss on ignition } \\
\end{array}$} & \multicolumn{2}{|c|}{42.25} & & & & & \\
\hline
\end{tabular}




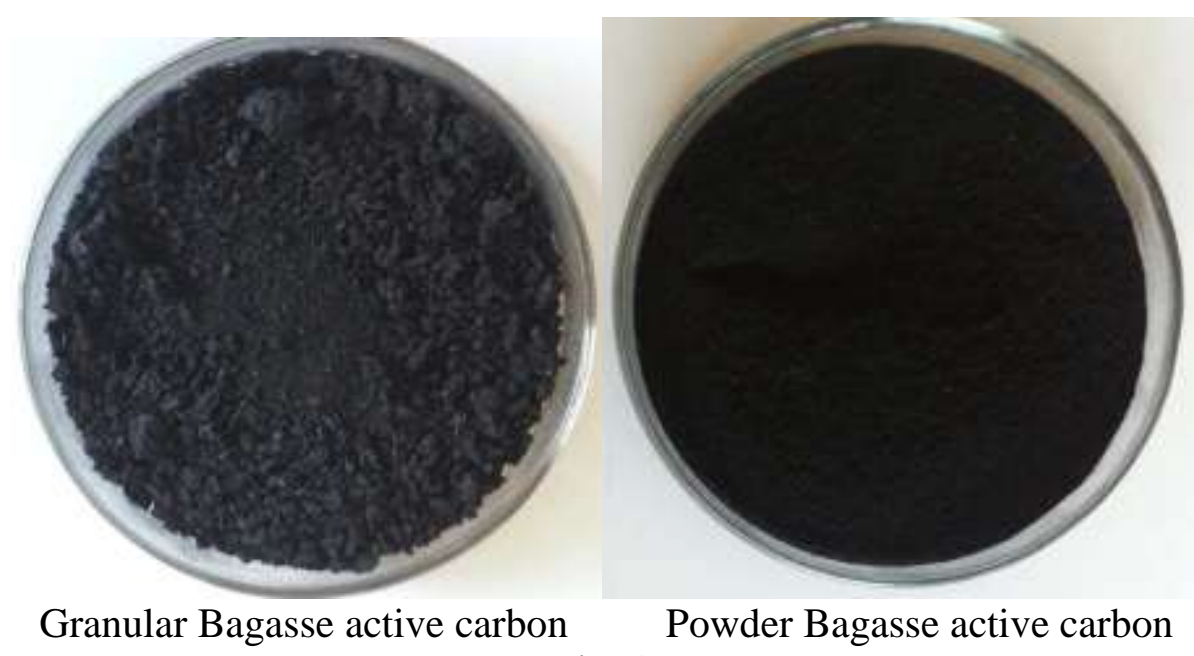

Fig. 1

\section{Overview of the porous characteristics of PAC and limestone by Multipoint (BET):}

The textural characterization of PAC and lime stone samples determination on $\mathrm{N} 2$ isotherms that used in mathematical models to quantify the specific surface area, pore volume and size distribution by BET area are shown in Table 2 and fig 1 to 8.

The BET plot in Fig. 1 and 6 indicated that the PAC has smaller pore size than lime stone meaning that PAC acquires the highest contribution of nanopores in its structure. Meanwhile the total pore volume occurs at about 0.1682 and $1.5847 \mathrm{~m}^{3} \mathrm{~g}^{-1}$, respectively. The samples had pointed out pore diameter of $2.1069 \mathrm{~nm}$ for PAC sample and 5.0349 for lime stone (table 2). The practical point of Fig 2 and 7 illustrated that it is fitting to use NLDFT/GCMC model which had depicted pore size distribution analysis for the used materials. Their pore size distributions in PAC and lime stone have nano pore in its structures. The first small occurs at about 2.1069 $\mathrm{nm}$ and the second at $5.0349 \mathrm{~nm}$ for mean pore diameter. Density Functional Theory by Model of isotherms pore size distribution analysis by NLDFT/GCMC as a fitting of the integral adsorption equation for description. The shape of adsorption isotherms in Fig $\mathbf{3}$ and 8 indicates that bagasse active carbon has the largest specific surface area compared to lime stone. The PAC has remarkable surface area up to $320 \mathrm{~m}^{2} / \mathrm{g}$ while the lime stone as expected has low surface area as $1.6 \mathrm{~m}^{2} / \mathrm{g}$. These results are in harmony with those obtained by (Benaddi et al., 2000, Ordóñez et al., 2014 and Changjia et al., 2019). 
Table (3) BET values for powder active carbon (PCA) and lime stone

\begin{tabular}{|c|c|c|}
\hline Parameters & PAC & lime stone \\
\hline \multicolumn{3}{|l|}{ BET plot } \\
\hline Mean pore diameter $(\mathrm{nm})$ & 2.1069 & 5.0349 \\
\hline Total pore volume $\left(\mathrm{m}^{3} \mathrm{~g}^{-1}\right)$ & 0.1682 & 1.5847 \\
\hline $\mathrm{a}_{\mathrm{s}} \mathrm{BET}^{2} \mathrm{~g}^{1}$ & 3.1923E+02 & $1.2590 \mathrm{E}+00$ \\
\hline \multicolumn{3}{|c|}{ Model of isotherms pore size distribution analysis by NLDFT/GCMC } \\
\hline Vp $\mathrm{cm}^{3} \mathrm{~g}^{-1}$ & 0.1793 & 1.0762 \\
\hline
\end{tabular}

In fact, it possesses the highest contribution of nano pore in its structure. This result may be due to lime stone has the largest contribution of the micro pore to its structure; unlike the PAC has the largest contribution of the nano pore, which earned it the highest adsorption capacity moreover, the production method which led to build narrow pore systems. Also, these results may be due to the performance indication of AC structure by pore size and the wall of the pore ranges from micro, macro, meso- pores. Eventually their distribution in a matrix depend on the source of the AC as well as the pore size distribution as affected by the nature of the chemical activating agent employed during activation (Karnib et. al., 2014).

Muli point of BET to get (surface area, porous volume, and pore size distribution)

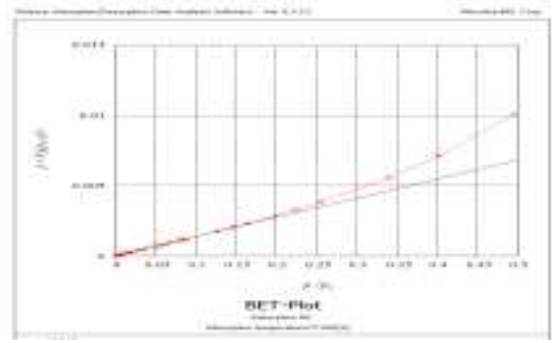

Fig. 1

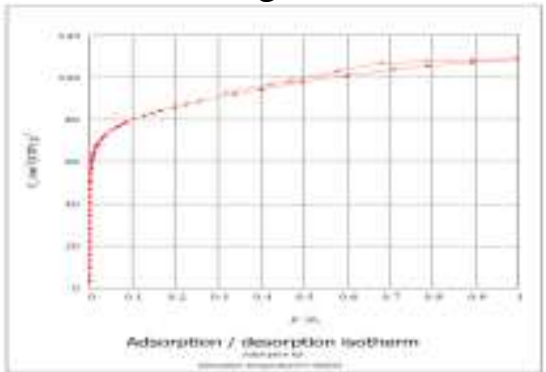

Fig. 3

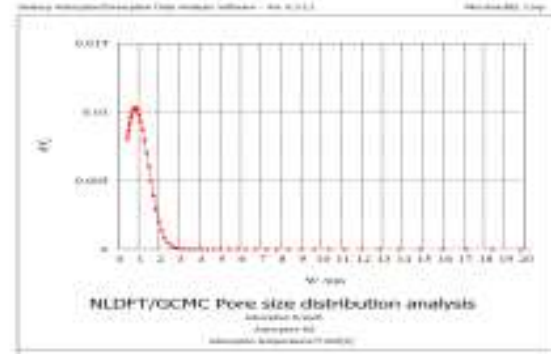

Fig. 2

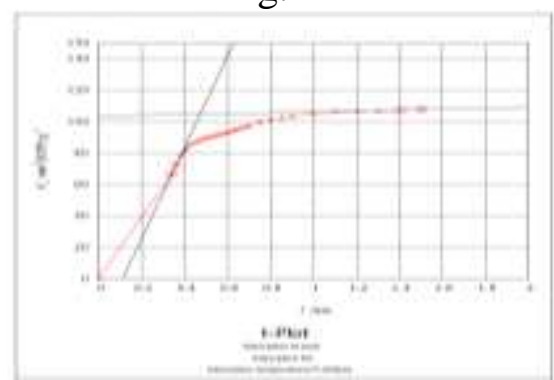

Fig. 4 


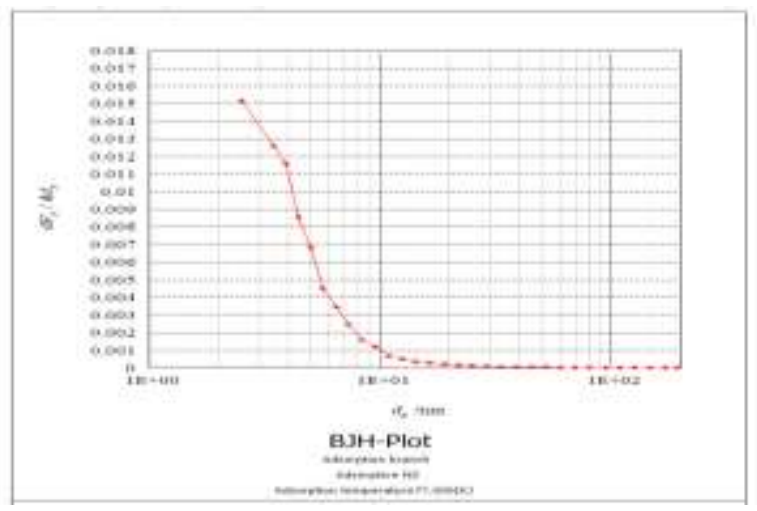

Fi.g 5

Fig: 1,2,3,4 and 5 Characteristics porous of bagasse activated carbon sample (surface area, pores volume, and pore size distribution, NLDFT/GCMC and DFT analyzed by BET area.

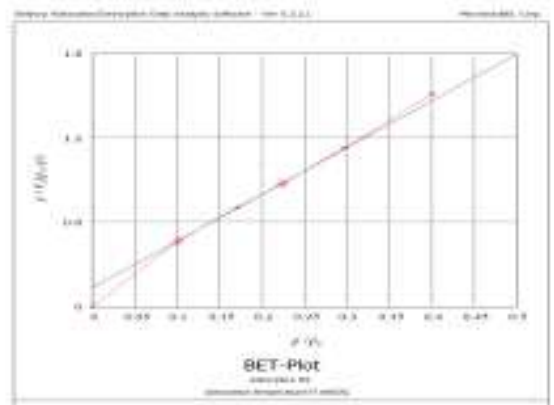

Fig. 6

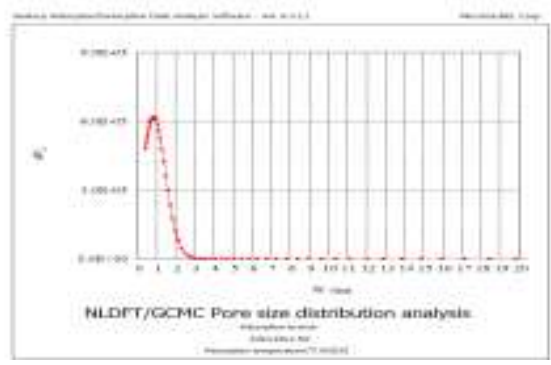

Fig. 7

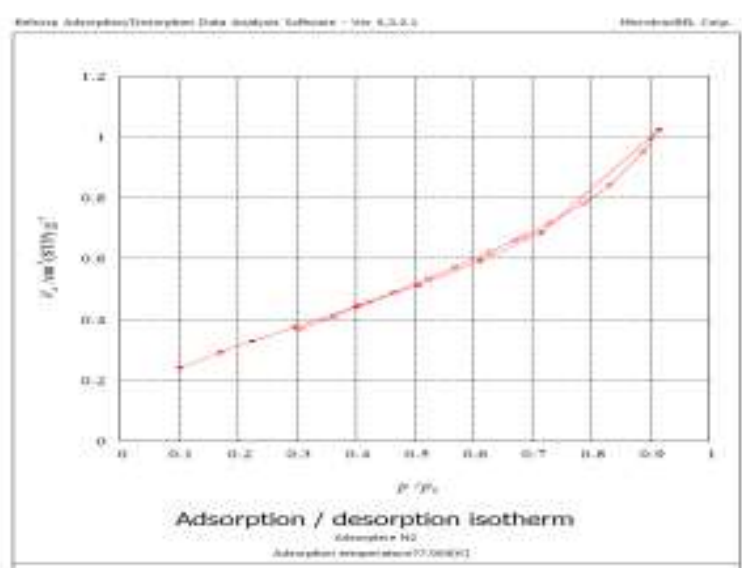

Fig. 8

Fig 6, 7 and 8 Characteristics porous of lime stone sample (surface area, pores volume, and pore size distribution, NLDFT/GCMC and DFT analyzed by BET area 


\section{Characterization of Synthesized Nano- Bagasse activated Carbon:}

Figure (9) show that the FTIR spectra of NAC product sample which point out the nano-particles from granulate activated carbon (NAC) sample revealed visible IR bands between 500 and $2000 \mathrm{~cm}^{-1}$. The large band represented at around $525 \mathrm{~cm}^{-1}$ may as a result of overlapping of $\mathrm{C}-\mathrm{O}-\mathrm{C}$ stretching, $\mathrm{C}-\mathrm{O}$ stretching and $\mathrm{O}$ bending modes of alcoholic, phenolic and carboxylic groups. The band at $1570 \mathrm{~cm}^{-1}$ is assigned to $\mathrm{C}=\mathrm{C}$ stretching conjugated with another $\mathrm{C}=\mathrm{C}$ bond, an aromatic nucleus, or $\mathrm{C}=\mathrm{O}$ bond. It has been reported that the $\mathrm{C}=\mathrm{C}$ stretching frequently occurs at approximately $1600 \mathrm{~cm}^{-1}$ for carbonaceous materials .The bands at more or less $2012 \mathrm{~cm}^{-1}$ are assigned to alkyl groups such as $-\mathrm{CH} 3,=\mathrm{CH} 2$ and $-\mathrm{CH} 2 \mathrm{CH} 3$. The weak band at around 3150 and $3700 \mathrm{~cm}^{-1}$ can assigned to the $\mathrm{O}-\mathrm{H}$ stretching vibration mode of hydroxyl functional groups. These surface efficient groups can provide active sites where chemical transformations take place via surface reactions. These data demonstrated that the most efficient prepared material represented as (NAC)

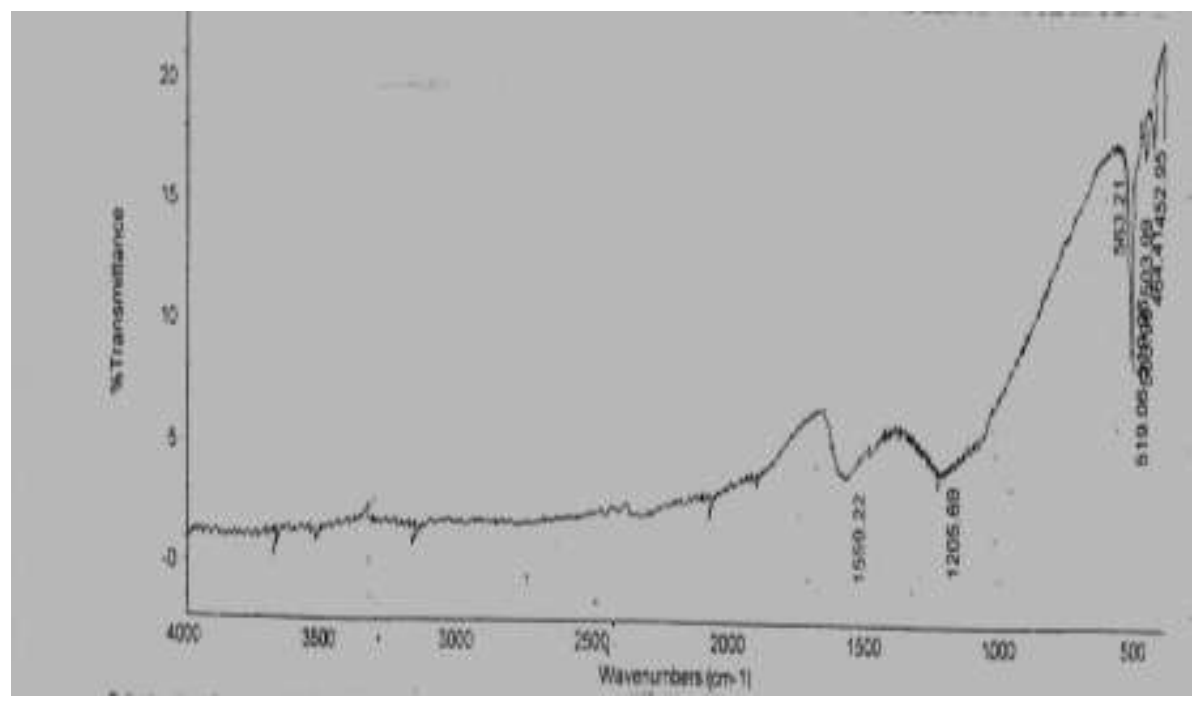

Fig. 9: FTIR spectrums of nano- Bagasse activated carbon

\section{Transmission Electron Microscopy (TEM):}

Figure (10) show that TEM images of GAC and PAC products which displayed a well pronounced the average particle size were about 400 to 410 for GAC and ranged from 174 to $200 \mathrm{~nm}$ for PAC meanwhile, TEM image of synthesized Nano- Bagasse activated Carbon 
I detected that the average of particle size ranged from 7.22 to $14.1 \mathrm{~nm}$. According to above results of BET and transmission electron microscopy (TEM), the most efficient forms is PAC and NAC because it had produced nano-scale by much higher surface area, pore volume, and porosity compared to GAC. These results are in harmony with those obtained by (Tancredi et al., 2004).

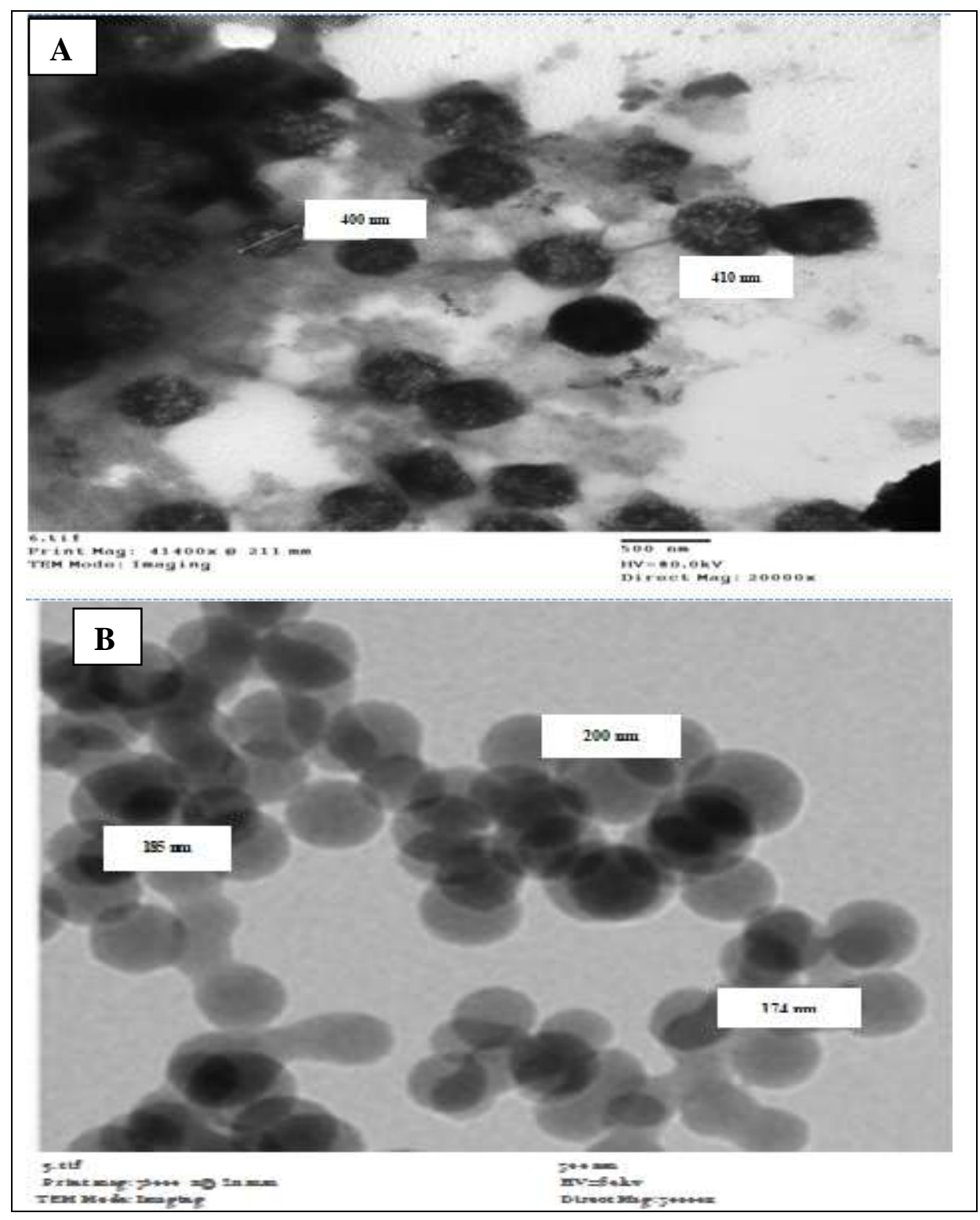




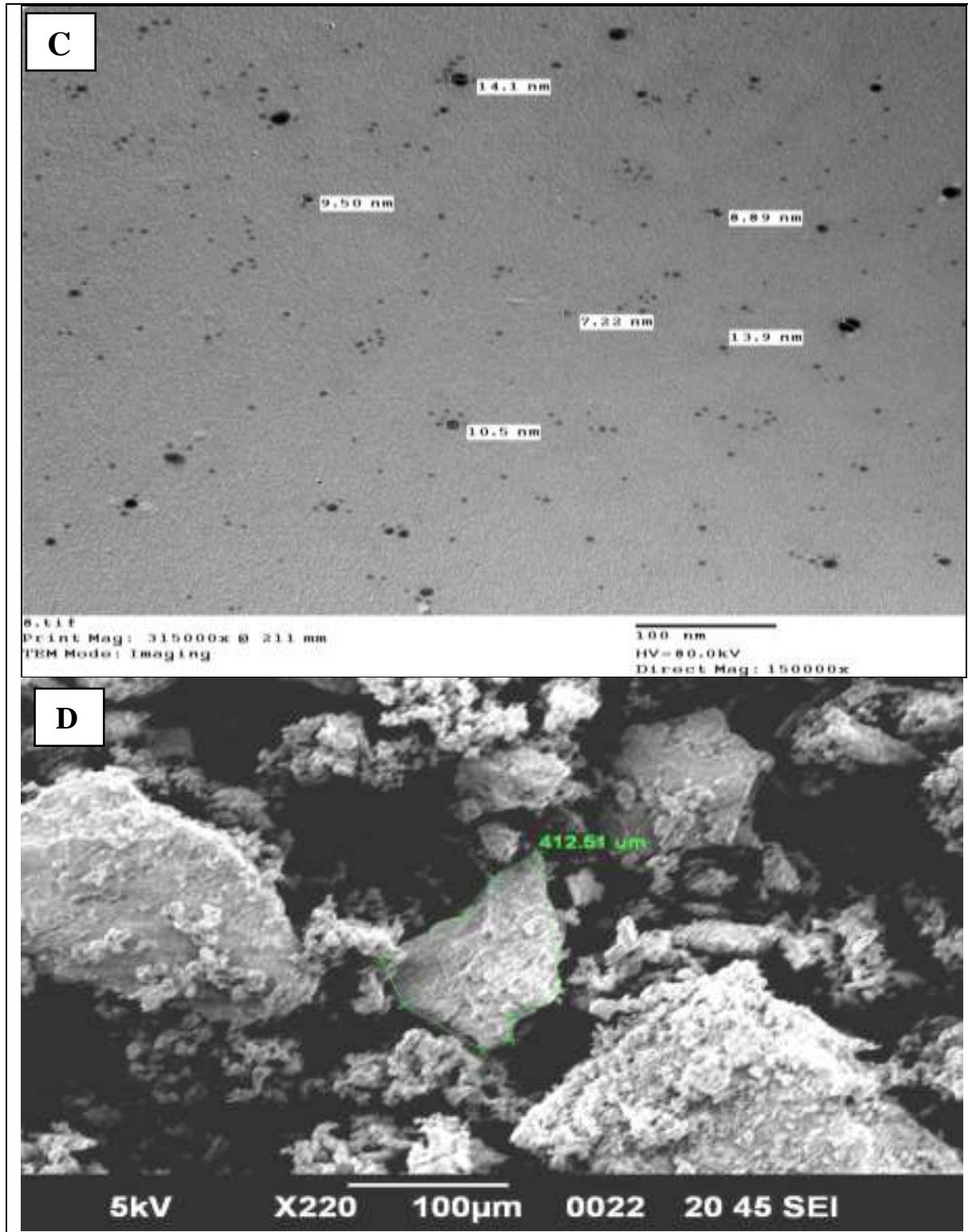

Fig 10: TEM images of GAC (A), PAC (B), NAC (c) and Limeston (D)

\section{Experimental applications on sewage water:}

Treatment sewage water by the fine powder of active carbon (PAC)

Data in Table (4) elucidate that PAC had a appreciable effects on all mention traits of sewage water compared to untreated water except, $\mathrm{pH}$ was not affected with all prolonging period under studied. 
Significant decreases in COD, BOD, SAR,TSS, NO3, Ca, Na, Cd, Cu, Fe and $\mathrm{Ni}$ in sewage water amounted by $(14.5,15.7) \mathrm{mg} \mathrm{O} 2 / \mathrm{L}$ and $(4.2$, $367.2,0.41,0.2,4.6,1.7$ and 4.3$) \mathrm{mg} / \mathrm{L}$ while, TDS was increased amounted to $299.4 \mathrm{mg} / \mathrm{L}$ after soaking period 10 days with zero time and without any significant differences among all soaking period for all traits except between soaking periods 10 and 15 days for PO4 and also between soaking periods of 15 and 20 days for TDS content of sewage water. Data in the same Table also clear that there is no significant difference among soaking periods 10, 15and 20 days for SAR, COD, BOD, TSS, NO3, Ca, Na, Cu, Cd, Fe and Ni. further, the same trend was detected for $\mathrm{Mg}$ between results of soaking periods (zero and 10) days and also between soaking periods (15 and 20) days for the same traits while it was found between soaking periods (10 and 15) days for ASR and TDS. These results are in harmony with those obtained by Ahn et al., (2009) and Hua et al., (2012) they found that PAC due to its high porosity, large surface area and high efficiency has gained more interests than the others. In addition the affected of PAC as a reported explain by Jung et al., (2013) who found that the maximum adsorption capacity of PAC reach to $46.9 \mathrm{mg} / \mathrm{g}$ for metal ions removal from aqueous solutions. Furthermore Tancredi et al., (2004) reported that (PAC) compared to granular activated carbon, has a much faster adsorption rate and a larger adsorption capacity of various organics usually related to their much higher surface area, pore volume, and porosity.

\section{Treatment sewage water by limestone:}

Data presented in table (5) show that treated sewage water by limestone had significant affect on SAR,TSS, COD, BOD, TDS, PO4, $\mathrm{NO} 3, \mathrm{Ca}, \mathrm{Mg}, \mathrm{Na}, \mathrm{Cd}, \mathrm{Cu}, \mathrm{Fe}$ and $\mathrm{Ni}$. Significant reduction resulted in soaking period 10 days in COD and BOD amounted to (3.9 and 4.9) $\mathrm{mgO} 2 / \mathrm{L}$ and also was $(369.4,0.3,0.13,3.2,1.7$ and 0.8$) \mathrm{mg} / \mathrm{L}$ for TSS, PO4, NO3, Ca, Mg and Na, respectively while was $(13.32,7.94,114.8$ and 19.2$) \mu \mathrm{g} / \mathrm{L}$ for $\mathrm{Cd}, \mathrm{Cu}, \mathrm{Fe}$ and $\mathrm{Ni}$, respectively except the value of TDS was increased amounted by $332.8 \mathrm{mg} / \mathrm{L}$ as compared to sewage water at zero time. On the other hand, increasing soaking period from zero to 15 days resulted in significant reduction in $\mathrm{PO}_{4}$ and $\mathrm{NO}_{3}$ and caused an increasing in TDS amounted by (0.41and 0.17) and 329.3 $\mathrm{mg} / \mathrm{L}$, respectively as compared to zero time. Meanwhile, other values of mention traits between soaking period from 10 and 15 in Table 6 was not affect 
Table (4) Effect of powder active carbon (PAC) on sewage water chemical composition

\begin{tabular}{|c|c|c|c|c|c|c|c|c|c|c|c|c|c|c|c|}
\hline \multirow{3}{*}{$\begin{array}{l}\text { S.P/ } \\
\text { day }\end{array}$} & \multicolumn{15}{|c|}{ powder active carbon (PAC) } \\
\hline & \multirow{2}{*}{ pH } & \multirow{2}{*}{ SAR } & COD & BOD & TSS & TDS & $\mathbf{P O}_{4}$ & $\mathrm{NO}_{3}$ & $\mathrm{Ca}$ & Mg & $\mathbf{N a}$ & $\mathrm{Cu}$ & Cd & $\mathbf{F e}$ & $\mathbf{N i}$ \\
\hline & & & \multicolumn{2}{|c|}{$\mathrm{mg} \mathrm{O}_{2} / \mathrm{L}$} & \multicolumn{8}{|c|}{$\mathrm{mg} / \mathrm{L}$} & \multicolumn{3}{|c|}{$\mu \mathrm{g} / \mathrm{L}$} \\
\hline zero & $7.4^{\mathrm{a}}$ & $15.4^{\mathrm{a}}$ & $92.3^{\mathrm{a}}$ & $63.6^{\mathrm{a}}$ & $377^{\mathrm{a}}$ & $12.4^{\mathrm{a}}$ & $\begin{array}{l}2.41^{\mathrm{a}} \\
\pm 0.1 \\
\end{array}$ & $\begin{array}{c}\mathbf{0 . 6 5}^{\mathrm{a}} \\
\pm 0.03 \\
\end{array}$ & $\begin{array}{r}38.4^{\mathrm{a}} \\
\pm 0.2\end{array}$ & $\begin{array}{c}14.8^{\mathrm{a}} \\
\pm 0.12\end{array}$ & $\begin{array}{c}58.6^{\mathrm{a}} \\
\pm 0.2\end{array}$ & $\begin{array}{l}17.6^{\mathrm{a}} \\
\pm 0.2\end{array}$ & $\begin{array}{c}13.6^{\mathrm{a}} \\
\pm 0.02\end{array}$ & $\begin{array}{c}306.2^{\mathrm{a}} \\
\pm 0.12\end{array}$ & $\begin{array}{c}45.7^{\mathrm{a}} \\
\pm 0.3\end{array}$ \\
\hline 10 & $7.2^{\mathrm{a}}$ & $11.2^{\mathrm{b}}$ & $77.8^{b}$ & $47.9^{\mathrm{b}}$ & $9.8^{\mathrm{b}}$ & $311.8^{b}$ & $\begin{array}{r}2.00^{b} \\
\pm 0.02\end{array}$ & $\begin{array}{c}0.45^{b} \\
\pm 0.02\end{array}$ & $\begin{array}{c}33.8^{\mathrm{b}} \\
\pm 0.1\end{array}$ & $\begin{array}{l}13.1^{\mathrm{a}} \\
\pm 0.11\end{array}$ & $\begin{array}{c}54.3^{\mathrm{b}} \\
\pm 0.1\end{array}$ & $\begin{array}{l}6.75^{b} \\
\pm 0.01\end{array}$ & $\begin{array}{l}\mathbf{8 . 8 1}^{\mathrm{b}} \\
\pm 0.03\end{array}$ & $\begin{array}{c}201.6^{b} \\
\pm 0.31\end{array}$ & $\begin{array}{c}{32.6^{b}}^{\mathrm{b}} \\
\pm 0.02\end{array}$ \\
\hline 15 & $7.2^{\mathrm{a}}$ & $10.8^{\mathrm{b}}$ & $76.5^{b}$ & $47.5^{\mathrm{b}}$ & $8.5^{\mathrm{b}}$ & $309.2^{b}$ & $\begin{array}{c}1.82^{\mathrm{c}} \\
\pm 0.01 \\
\end{array}$ & $\begin{array}{r}0_{0.41} \\
\pm 0.01 \\
\end{array}$ & $\begin{array}{c}33.6^{b} \\
\pm 0.1\end{array}$ & $\begin{array}{r}12.9^{b} \\
\pm 0.10\end{array}$ & $\begin{array}{l}54.2^{b} \\
\pm 0.2\end{array}$ & $\begin{array}{c}6.44^{b} \\
\pm 0.02\end{array}$ & $\begin{array}{c}8^{8.53}{ }^{\mathrm{b}} \\
\pm 0.02\end{array}$ & $\begin{array}{c}200.3^{b} \\
\pm 0.24\end{array}$ & $\begin{array}{r}32.5^{\mathrm{b}} \\
\pm 0.01\end{array}$ \\
\hline 20 & $7.2^{\mathrm{a}}$ & $10.7^{\mathrm{b}}$ & $72.8^{b}$ & $48.1^{\mathrm{b}}$ & $8.1^{\mathrm{b}}$ & $300.7^{\mathrm{c}}$ & $\begin{array}{l}1.75^{\mathrm{c}} \\
\pm 0.02\end{array}$ & $\begin{array}{c}0.40^{\mathrm{b}} \\
\pm 0.01\end{array}$ & $\begin{array}{c}33.7^{6} \\
\pm 0.1\end{array}$ & $\begin{array}{l}12.3^{b} \\
\pm 0.11\end{array}$ & $\begin{array}{c}5_{4.2}{ }^{\mathrm{b}} \\
\pm 0.1\end{array}$ & $\begin{array}{c}6.38^{b} \\
\pm 0.02\end{array}$ & $\begin{array}{c}8.52^{b} \\
\pm 0.03\end{array}$ & $\begin{array}{c}200^{b} \\
\pm 0.17\end{array}$ & $\begin{array}{l}3^{32.6^{6}} \\
\pm 0.01\end{array}$ \\
\hline
\end{tabular}

S.P: soaking period, SAR: sodium adsorption ratio, COD: Chemical oxygen demand, BOD: biological oxygen demand,TSS: total soluble solids,TDS: total dissolved solids

Values with different letters show significant differences at $\mathbf{P} \leq .05$ (LSD).

\section{Table 5: Effect of lime stone on sewage water treatment}

\begin{tabular}{|c|c|c|c|c|c|c|c|c|c|c|c|c|c|c|c|}
\hline \multirow{3}{*}{$\begin{array}{l}\text { S.P/ } \\
\text { day }\end{array}$} & \multicolumn{15}{|c|}{ lime stone } \\
\hline & \multirow{2}{*}{ pH } & \multirow{2}{*}{ SAR } & COD & BOD & TSS & TDS & $\mathrm{PO}_{4}$ & $\mathrm{NO}_{3}$ & $\mathbf{C a}$ & Mg & $\mathrm{Na}$ & $\mathrm{Cu}$ & Cd & $\mathrm{Fe}$ & $\mathrm{Ni}$ \\
\hline & & & \multicolumn{2}{|c|}{$\mathrm{mg} \mathrm{O}_{2} / \mathrm{L}$} & \multicolumn{8}{|c|}{$\mathrm{mg} / \mathrm{L}$} & \multicolumn{3}{|c|}{$\mu \mathrm{gg} / \mathrm{L}$} \\
\hline zero & $7.4^{\mathrm{a}}$ & $15.4^{\mathrm{a}}$ & $92.3^{a}$ & $63.6^{\mathrm{a}}$ & $377^{\mathrm{a}}$ & $12.4^{\mathrm{a}}$ & $\begin{array}{l}2.41^{\mathrm{a}} \\
\pm 0.1\end{array}$ & $\begin{array}{l}0.65^{\mathrm{a}} \\
\pm 0.03\end{array}$ & $\begin{array}{l}38.4^{\mathrm{a}} \\
\pm 0.2\end{array}$ & $\begin{array}{l}14.8^{\mathrm{a}} \\
\pm 0.12\end{array}$ & $\begin{array}{l}58.6^{\mathrm{a}} \\
\pm \mathbf{0 . 2}\end{array}$ & $\begin{array}{l}17.6^{\mathrm{a}} \\
\pm 0.2\end{array}$ & $\begin{array}{l}13.6^{\mathrm{a}} \\
\pm 0.02\end{array}$ & $\begin{array}{l}306.2^{\mathrm{a}} \\
\pm 0.12\end{array}$ & $\begin{array}{l}45.7^{\mathrm{a}} \\
\pm 0.3\end{array}$ \\
\hline 10 & $7.3^{\mathrm{a}}$ & $11.8^{\mathrm{b}}$ & $88.4^{b}$ & $58.7^{b}$ & $7.6^{\mathrm{b}}$ & $345.2^{\mathrm{b}}$ & $\begin{array}{l}2.11^{b} \\
\pm 0.03\end{array}$ & $\begin{array}{l}0.52^{b} \\
\pm 0.02\end{array}$ & $\begin{array}{l}35.2^{\mathrm{b}} \\
\pm 0.3\end{array}$ & $\begin{array}{l}13.1^{b} \\
\pm 0.11\end{array}$ & $\begin{array}{l}57.8^{\mathrm{b}} \\
\pm 0.1\end{array}$ & $\begin{array}{l}8.70^{\mathrm{b}} \pm \\
0.2\end{array}$ & $\begin{array}{l}11.4^{b} \\
\pm 0.01\end{array}$ & $\begin{array}{l}249.2^{\mathrm{b}} \\
\pm 0.20\end{array}$ & $\begin{array}{l}41.6^{\mathrm{b}} \\
\pm 0.14\end{array}$ \\
\hline 15 & $7.3^{\mathrm{a}}$ & $11.8^{\mathrm{a}}$ & $85.7^{b}$ & $58.3^{b}$ & $7.1^{b}$ & $341.7^{c}$ & $\begin{array}{l}2.00^{\mathrm{c}} \\
\pm 0.02\end{array}$ & $\begin{array}{l}0.48^{\mathrm{c}} \\
\pm 0.03\end{array}$ & $\begin{array}{l}35.2^{b} \\
\pm 0.4\end{array}$ & $\begin{array}{l}13.0^{b} \\
\pm 0.11\end{array}$ & $\begin{array}{l}57.6^{b} \\
\pm 0.1\end{array}$ & $\begin{array}{l}8.50^{b} \\
\pm 0.3\end{array}$ & $\begin{array}{l}10.2^{b} \\
\pm 0.01\end{array}$ & $\begin{array}{l}248.5^{b} \\
\pm 0.22\end{array}$ & $\begin{array}{l}41.5^{b} \\
\pm 0.12\end{array}$ \\
\hline 20 & $7.3^{\mathrm{a}}$ & $11.7^{\mathrm{a}}$ & $80.6^{\mathrm{c}}$ & $58.5^{b}$ & $7.1^{b}$ & $341.6^{c}$ & $\begin{array}{l}1.98^{\mathrm{c}} \\
\pm 0.02\end{array}$ & $\begin{array}{l}0.48^{\mathbf{c}} \\
\pm 0.02\end{array}$ & $\begin{array}{l}35.1^{\mathrm{b}} \\
\pm 0.3\end{array}$ & $\begin{array}{l}13.0^{b} \\
\pm 0.10\end{array}$ & $\begin{array}{l}56.4^{\mathrm{b}} \\
\pm 0.02\end{array}$ & $\begin{array}{l}7.66^{c} \\
\pm 0.2\end{array}$ & $\begin{array}{l}10.0^{b} \\
\pm 0.01\end{array}$ & $\begin{array}{l}241.6^{c} \\
\pm 0.21\end{array}$ & $\begin{array}{l}41.0^{b} \\
\pm 0.1\end{array}$ \\
\hline
\end{tabular}


Increasing soaking period from zero to 20 days resulted in a significant reduction in $\mathrm{COD}, \mathrm{Cu}$ and $\mathrm{Fe}$ amounted by $11.7 \mathrm{mgO}_{2} / \mathrm{L}$, (9.94 and 64.6) $\mu \mathrm{g} / \mathrm{L}$ respectively compared to zero time. Moreover, there is no difference between soaking period from 15 and 20 days for the other values of all mention traits in Table 5. The different absorption capacities of limestone substance through different soaking period zero, 10,15 up to 20 days may be attributed to various factors such as metal solubility, cationic size, electronegativity, affinity of adsorbent, contact time etc as a mentioned by Geetha and Belagali (2013). This results coincides with those found by Ahmad et al., (2012) who reported that $\mathrm{CaCO} 3$ showed a good metal binding capability for heavy metals ions and can be used an effective alternative from real wastewater metal removal.

\section{Treatment sewage water by nano active carbon (NAC):}

Data in Table (6) elucidate that nano active carbon had a appreciable high effects on all traits of sewage water with increased soaking period from zero to 10 days except $\mathrm{pH}$ value was insignificantly affected by the prolonging period from zero, 10, 15 to 20 days after treated. The results also showed that there no detected any significant differences among all other soaking period and zero time for all above traits in Table 6 except, Fe was obtained significant decrease which amounted to (8.9 and 123.7) $\mu \mathrm{g} / \mathrm{L}$ in soaking periods 10 and 15 days, respectively after treatments as well as increasing soaking period from zero to 20 caused an increase in TDS and reducing NO3 which amounted to $(248.9$ and0.05) $\mathrm{mg} / \mathrm{L}$ as a compared to zero time. It worthily to mention the corresponding reduction values for all traits in Table 6 were highest as compared to the other treatment materials. This finding was true when refer to table (2). These results may be attributed to the fact that PAC has a relatively larger particle size compared to NAC and consequently, presents a smaller external surface. These results are in line with those obtained by Elkady et al., (2015) who found that NAC exhibited array of unique performance for improvement properties of sewage water like deodorization and heavy metal removal.

In accordance with previous results in table 3,4 and 5 about the performance indication of individual effect of each PAC, lime and NAC stone on sewage water chemical composition, the results observed that NAC treatment was high effects than the other materials so that, it was selected to study the effects of using it in combination with lime stone on the disposal of some chemical composition found in sewage water table 7 and SEM images for combination NAC + lime stone was investigated at Fig.11 
Table 6: Effect of Nano active carbon (NAC) on sewage water treatment

\begin{tabular}{|c|c|c|c|c|c|c|c|c|c|c|c|c|c|c|c|}
\hline \multirow{3}{*}{$\begin{array}{l}\text { S.P/ } \\
\text { day }\end{array}$} & \multicolumn{15}{|c|}{ Nano active carbon (NAC) } \\
\hline & \multirow{2}{*}{ pl } & \multirow{2}{*}{$\mathbf{A R}$} & COD & BOD & TSS & TDS & $\mathrm{PO}_{4}$ & $\mathrm{NO}_{3}$ & $\mathbf{C a}$ & Mg & $\mathbf{N a}$ & $\mathrm{Cu}$ & Cd & $\mathbf{F e}$ & $\mathbf{N i}$ \\
\hline & & & \multicolumn{2}{|c|}{$\mathrm{mg} \mathrm{O}_{2} / \mathrm{L}$} & \multicolumn{8}{|c|}{$\mathrm{mg} / \mathrm{L}$} & \multicolumn{3}{|c|}{$\mu \mathrm{g} / \mathrm{L}$} \\
\hline zero & $7.4^{\mathrm{a}}$ & $15.4^{\mathrm{a}}$ & $92.3^{\mathrm{a}}$ & $63.6^{\mathrm{a}}$ & $377^{\mathrm{a}}$ & \begin{tabular}{|c|}
12.4 \\
$a$
\end{tabular} & \begin{tabular}{|l|}
$2.41^{\mathrm{a}}$ \\
\pm 0.1 \\
\end{tabular} & \begin{tabular}{|c|}
$0.65^{\mathrm{a}}$ \\
$\mathbf{\pm 0 . 0 3}$ \\
\end{tabular} & $\begin{array}{c}38.4^{\mathrm{a}} \\
\pm 0.2 \\
\end{array}$ & \begin{tabular}{|l|}
$14.8^{\mathrm{a}}$ \\
\pm 0.12 \\
\end{tabular} & \begin{tabular}{|c|}
$58.6^{\mathrm{a}}$ \\
\pm 0.2 \\
\end{tabular} & \begin{tabular}{|c|}
$17.6^{\mathrm{a}}$ \\
\pm 0.2 \\
\end{tabular} & $\begin{array}{r}13.6^{\mathrm{a}} \\
\pm 0.02 \\
\end{array}$ & \begin{tabular}{|c|}
$306.2^{\mathrm{a}}$ \\
\pm 0.12 \\
\end{tabular} & \begin{tabular}{|c|}
$45.7^{\mathrm{a}}$ \\
\pm 0.3 \\
\end{tabular} \\
\hline 10 & $7.1^{\mathrm{a}}$ & $10.1^{b}$ & $58.3^{b}$ & $44.2^{\mathrm{b}}$ & $7.6^{b}$ & $267.5^{b}$ & \begin{tabular}{|l|}
$1.61^{\mathrm{b}}$ \\
$\pm \mathbf{0 . 0 2}$
\end{tabular} & \begin{tabular}{|c|}
$\mathbf{0 . 3 8}^{\mathrm{b}}$ \\
$\mathbf{\pm 0 . 0 2}$ \\
\end{tabular} & $\begin{array}{l}32.1^{b} \\
\pm 0.11\end{array}$ & \begin{tabular}{|c|}
$11.8^{b}$ \\
\pm 0.13 \\
\end{tabular} & $\begin{array}{c}51.6^{b} \\
\pm 0.3\end{array}$ & \begin{tabular}{|c|}
$4.28^{b}$ \\
\pm 0.1 \\
\end{tabular} & $\begin{array}{l}5.66^{b} \\
\pm 0.03 \\
\end{array}$ & $\begin{array}{c}191.4^{\mathrm{b}} \\
\pm 0.45 \\
\end{array}$ & $\begin{array}{l}26.5^{\mathrm{b}} \\
\pm 0.11 \\
\end{array}$ \\
\hline 15 & $7.1^{\mathrm{a}}$ & $10.0^{b}$ & $56.5^{b}$ & $42.8^{b}$ & $7.1^{b}$ & $267.1^{b}$ & $\begin{array}{c}1.51^{b} \\
\pm 0.01\end{array}$ & $\begin{array}{c}\mathbf{O . 3 8}_{ \pm 0 .}^{\mathrm{b}} \\
\pm 0.02\end{array}$ & $\begin{array}{l}31.5^{b} \\
\pm 0.13\end{array}$ & $\begin{array}{c}11.8^{b} \\
\pm 0.11\end{array}$ & $\begin{array}{c}50.2^{b} \\
\pm 0.3\end{array}$ & $\begin{array}{c}3.06^{b} \\
\pm 0.1\end{array}$ & $\begin{array}{l}5.48^{b} \\
\pm 0.04\end{array}$ & $\begin{array}{r}182.5^{\mathrm{c}} \\
\pm 0.41\end{array}$ & $\begin{array}{c}22^{23 .} 6^{b} \\
\pm 0.13\end{array}$ \\
\hline 20 & $7.1^{\mathrm{a}}$ & $10.0^{b}$ & $56.3^{b}$ & $42.3^{\mathrm{b}}$ & $7.1^{b}$ & $261.3^{\mathrm{c}}$ & $\begin{array}{l}1.50^{b} \\
\pm 0.02\end{array}$ & \begin{tabular}{|c|}
$\mathbf{0 . 3 3}^{\mathrm{c}}$ \\
$\mathbf{\pm 0 . 0 3}$
\end{tabular} & $\begin{array}{l}31.2^{\mathrm{b}} \\
\pm 0.20\end{array}$ & $\begin{array}{l}11.5^{b} \\
\pm 0.11\end{array}$ & $\begin{array}{l}49.1^{\mathrm{b}} \\
\pm 0.2\end{array}$ & $\begin{array}{c}2.03^{\mathrm{b}} \\
\pm 0.2\end{array}$ & $\begin{array}{c}4.92^{\mathrm{b}} \\
\pm 0.01\end{array}$ & $\begin{array}{c}180.1^{\mathrm{c}} \\
\pm 0.32\end{array}$ & \begin{tabular}{|c|}
$20.2^{\mathrm{b}}$ \\
\pm 0.11
\end{tabular} \\
\hline
\end{tabular}

Values with different letters show significant differences at $\mathrm{P} \leq .05$ (LSD).

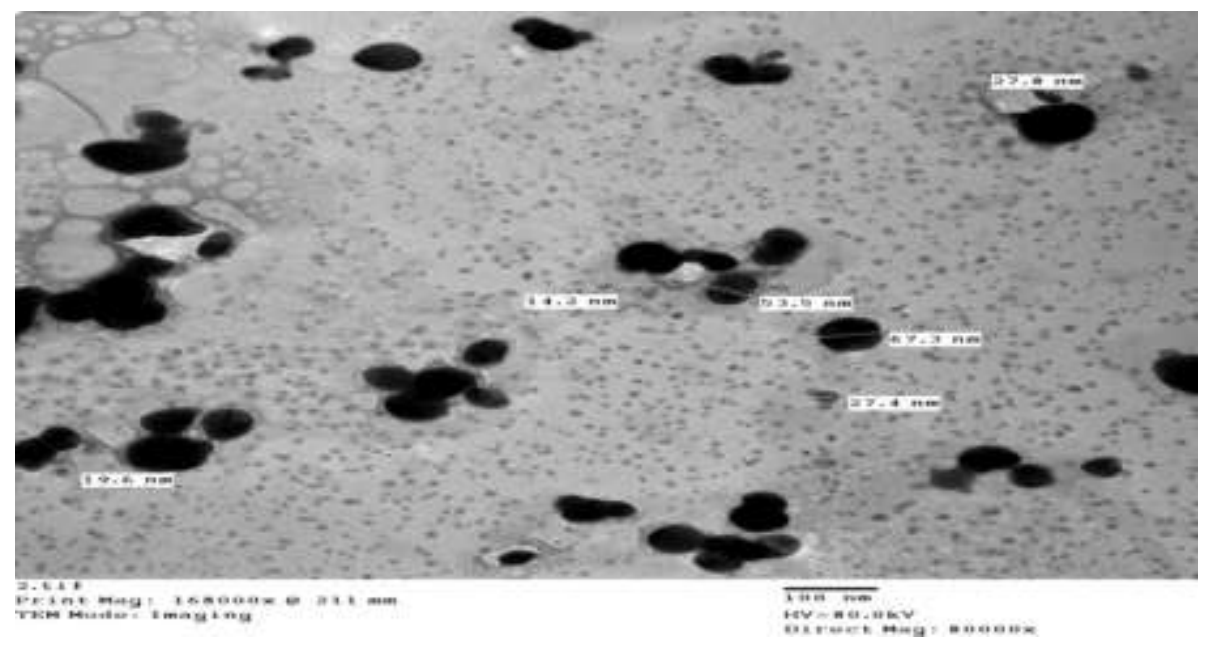

Fig. 11: TEM images of combination NAC + lime stone

\section{Treatment sewage water by combination of (NAC + lime stone):}

The results in Table (7) declared that all chemical traits of sewage water were significantly affected by using nano active carbon in combination with limestone. Significant decreasing in all mentioned traits in Table 7 with increased soaking period from zero, 10, 15 up to 20 days excepted, trait of TDS was increase while, $\mathrm{pH}$ value was not affected by all prolonging periods. Treatment sewage water by combination of (NAC + lime stone) achieved substantial decrements after soaking period 10 day amounted to $(36.9,26) \mathrm{mg} \mathrm{O}_{2} / \mathrm{L}$ for COD and BOD and amounted to $(5.6,370.2,1.67,0.38,8.6,4.5,10) \mathrm{mg} / \mathrm{L}$ for SAP, TSS, PO4, NO3, Ca, Mg and $\mathrm{Na}$ and amounted to (13.24, 9.75, 133.6 and 30.9) $\mu \mathrm{g} / \mathrm{L}$ for $\mathrm{Cd}, \mathrm{Cu}, \mathrm{Fe}$ and $\mathrm{Ni}$ content, respectively and 
trait of TDS increasing amounted to $246.4 \mathrm{mg} / \mathrm{L}$ compared to that of untreated sewage water. Also in the same Table, it was noticed that insignificant variances were found in SAR, COD, TSS, Ca, Mg and $\mathrm{Na}$ traits among their values in soaking period 10, 15 and 20 days. While, the significant difference was detected between soaking periods 15 and 20 days for TDS and $\mathrm{PO}_{4}$ as well as between soaking period15 and 20 days for $\mathrm{BOD}, \mathrm{NO}_{3}, \mathrm{Cu}, \mathrm{Cd}, \mathrm{Fe}$ and $\mathrm{Ni}$. These results may be attributed to various factors such as metal solubility, cationic size, electro negativity, affinity of adsorbent, contact time etc as a mentioned by Geetha and Belagali (2013). This finding meaning using this combination for water treatment it can be achieve impressive results for removal some ions of metal oxides and heavy metals as well as reducing chemical and biological oxygen demand in sewage water.

Table 7: Effect of combination of (NAC + lime stone) on sewage water treatment

\begin{tabular}{|c|c|c|c|c|c|c|c|c|c|c|c|c|c|c|c|}
\hline \multirow{3}{*}{$\begin{array}{l}\text { S.P/ } \\
\text { day }\end{array}$} & \multicolumn{15}{|c|}{ combination $0.5 \mathrm{mg} / \mathrm{l} \mathrm{NAC}+6 \mathrm{~g} / \mathrm{l}$ lime stone } \\
\hline & \multirow{2}{*}{ pH } & \multirow{2}{*}{ SAR } & OD & BOD & TSS & TDS & PO4 & NO3 & $\mathrm{Ca}$ & Mg & $\mathrm{Na}$ & $\mathbf{C u}$ & Cd & $\mathbf{F e}$ & $\mathbf{N i}$ \\
\hline & & & \multicolumn{2}{|c|}{$\mathrm{mg} \mathrm{O2/L}$} & \multicolumn{8}{|c|}{$\mathbf{m g} / \mathbf{L}$} & \multicolumn{3}{|c|}{$\mu \mathrm{g} / \mathrm{L}$} \\
\hline zero & $7.4^{\mathrm{a}}$ & $15.4^{\mathrm{a}}$ & $92.3^{\mathrm{a}}$ & $63.6^{\mathrm{a}}$ & $377^{\mathrm{a}}$ & $12.4^{\mathrm{a}}$ & & & $\begin{array}{l}38.4^{\mathrm{a}} \\
\pm 0.2\end{array}$ & & $\begin{array}{c}58.6^{\mathrm{a}} \\
\pm 0.2\end{array}$ & $\begin{array}{l}17.6^{\mathrm{a}} \\
\pm 0.2\end{array}$ & $\begin{array}{c}13.6^{\mathrm{a}} \\
\pm 0.02\end{array}$ & $\begin{array}{l}306.2^{\mathrm{a}} \\
\pm 0.12\end{array}$ & $\begin{array}{c}45.7^{\mathrm{a}} \\
\pm 0.3\end{array}$ \\
\hline 10 & $7.1^{\mathrm{a}}$ & $9.8^{\mathrm{b}}$ & $55.4^{\mathrm{b}}$ & $37.6^{b}$ & $6.8^{b}$ & $258.8^{b}$ & & & $\begin{array}{l}29.8^{b} \\
\pm 0.1\end{array}$ & & $\begin{array}{l}48.6^{b} \\
\pm 0.1\end{array}$ & $\begin{array}{r}4.36^{b} \\
\pm 0.04\end{array}$ & $\begin{array}{r}3.85^{b} \\
\pm 0.03\end{array}$ & $\begin{array}{c}170.6^{b} \\
\pm 0.13\end{array}$ & $\begin{array}{r}14.8^{b} \\
\pm 0.3\end{array}$ \\
\hline 15 & $7.1^{\mathrm{a}}$ & & $55.1^{\mathrm{b}}$ & $35.5^{\mathrm{c}}$ & $6.3^{b}$ & $258.1^{b}$ & $\begin{array}{c}0.72^{\mathrm{b}} \\
\pm 0.02\end{array}$ & $\begin{array}{c}0.21^{\mathrm{c}} \\
\pm 0.02\end{array}$ & $\begin{array}{l}29.5^{b} \\
\pm 0.1\end{array}$ & & $\begin{array}{l}46.5^{b} \\
\pm 0.2\end{array}$ & $\begin{array}{l}3.89^{c} \\
\pm 0.03\end{array}$ & $\begin{array}{c}1.81^{\mathrm{c}} \\
\pm 0.05\end{array}$ & $\begin{array}{l}162.3^{\mathrm{c}} \\
\pm 0.11\end{array}$ & $\begin{array}{l}13.7^{\mathrm{c}} \\
\pm 0.1\end{array}$ \\
\hline 20 & $7.1^{\mathrm{a}}$ & & $54.2^{\mathrm{b}}$ & $35.6^{\mathrm{c}}$ & $6.3^{b}$ & $253.4^{c}$ & \begin{tabular}{|c|}
$0.58^{c}$ \\
\pm 0.03 \\
\end{tabular} & $\begin{array}{c}0.20^{c} \\
\pm 0.02\end{array}$ & $\begin{array}{l}25.5^{b} \\
\pm 0.2\end{array}$ & $\begin{array}{c}8.3^{\mathrm{b}} \\
\pm 0.05\end{array}$ & $\begin{array}{l}45.2^{\mathrm{b}} \\
\pm 0.2\end{array}$ & $\begin{array}{l}2.81^{c} \\
\pm 0.05\end{array}$ & $\begin{array}{r}1.28^{c} \\
\pm 0.05\end{array}$ & $\begin{array}{c}154.8^{\mathrm{c}} \\
\pm 0.12\end{array}$ & $\begin{array}{l}12.1^{\mathrm{c}} \\
\pm 0.1\end{array}$ \\
\hline
\end{tabular}

Values with different letters show significant differences at $\mathbf{P} \leq .05$ (LSD).

Data presented in Table 8 show that water treatments under studied were arranged in ascending order according to the removal\% of chemical contents. This ranking refer to the good reflect of using NAC in combination with limestone as a better treatment on enhancing sewage water quality. The removals of unwanted traits by the combination (NAC+ Lime stone) may be related to the function activity of surface area and also nano particles has a special properties i.e. high wide specific surface area, high reactivity, tunable pore size, which may allow them access to the maximum adsorption capacity and larger adsorption porosity moreover, the capability of limestone as a tool in water treatment and carriers to nano particles at the same time.

Table 8: Removal \% for all sewage water treatments after soaking period 10 days

\begin{tabular}{|c|c|c|c|c|c|c|c|c|c|c|c|c|c|c|}
\hline \multirow{2}{*}{\multicolumn{2}{|c|}{ Treatments }} & SAR & COD & BOD & TSS & $\mathrm{PO}_{4}$ & $\mathrm{NO}_{3}$ & $\mathrm{Ca}$ & Mg & $\mathrm{Na}$ & $\mathrm{Cu}$ & Cd & $\mathbf{F e}$ & $\mathbf{N i}$ \\
\hline & & & \multicolumn{2}{|c|}{$\%$} & \multicolumn{7}{|c|}{$\%$} & \multicolumn{3}{|c|}{$\%$} \\
\hline 1 & Limestone & 0.23 & 0.04 & 0.08 & 0.98 & 0.12 & 0.2 & 0.08 & 0.11 & 0.009 & 0.51 & 0.16 & 0.17 & 0.09 \\
\hline 2 & PAC & 0.27 & 0.16 & 0.25 & 0.97 & 0.17 & 0.31 & 0.12 & 0.12 & 0.07 & 0.62 & 0.35 & 0.34 & 0.29 \\
\hline 3 & NAC & 0.34 & 0.37 & 0.31 & 0.98 & 0.33 & 0.41 & 0.16 & 0.20 & 0.12 & 0.75 & 0.58 & 0.37 & 0.42 \\
\hline 4 & $\begin{array}{c}\text { NAC + } \\
\text { Lime stone }\end{array}$ & 0.36 & 0.40 & 0.41 & 0.98 & 0.69 & 0.58 & 0.22 & 0.30 & 0.17 & 0.75 & 0.71 & 0.44 & 0.67 \\
\hline
\end{tabular}




\section{CONCLUSION}

Producing powder activated carbon and/or synthesis of activated carbon nano-particles (NAC) from sugar cane bagasse is considered one of successful trying up grate agricultural waste treatment technologies. Combination treatment (NAC + limestone) exhibited unique performance for reducing some pollutants from sewage water.

\section{REFERENCES}

A.O.A.C. (2010). Association of Official Agricultural Chemist. Official Methods of Analysis published by the A.O.A.C., Box 540, Washington, U.S.A.

Ahmad, K. ; A.B. Ijaz ; M. Majid ; I. Munawar and I.Zafar (2012). Removal of heavy metals ( $\mathrm{Zn}, \mathrm{Cr}, \mathrm{Pb}, \mathrm{Cd}, \mathrm{Cu}$ and $\mathrm{Fe}$ ) in aqueous media by calcium carbonate as an adsorbent. International Journal of Chemical and Biochemical Sciences (IJCBS), PP: 48-53

Ahn, C.K. ; D. Park ; S.H. Woo and J.M. Park (2009). Removal of cationic heavy metal from aqueous solution by activated carbon impregnated with anionic surfactants. J Hazard Mater, 164:1130-1136.

Ajinomoh, C. S. and N. Salahudeen (2014). Production of Activated Carbon from Sugar Cane Bagasse. Australian Journal of Industry Research, SCIE Journals: 16-22. https://www.researchgate.net/publication/283082790

Almuktar, S.A.N. ; S.N. Abed and M. Scholz (2018). Wetlands for wastewater treatment and subsequent recycling of treated effluent: a review. Environ Sci Pollut Res., 25:23595-23623

Aziz, H.A.; N. Othman ; M.S. Yusuff; D.R. Basri ; F.A. Ashaari; M.N. Adlan ;F. Othman; M. Johari and M. Perwira (2001). Removal of copper from water using limestone filtration technique: determination of mechanism of removal. Environment international, 26: 395-399.

Bao, J.M. (2011). Adsorption Mechanism of activated carbon and its Application inWater treatment. J. Sichuan Environ., 11(2): 97-100.

Benaddi, H.;T.J. Bandosz; J. Jageillo; J.A. Schwarz and J.N. Rouzaud (2000).Surface Functionality and Porosity of Activated Carbons Obtained from Chemical Activation of Wood. J. Carbon.,38:669-674.

Changjia, J.; C. Shuang; H. Qing; L. Ping; Z. Qikai1; S. Jianhui and L. Mingrui (2019). Study on Application of Activated Carbon in Water Treatment. IOP Conf. Series: Earth and Environmental Science 237 (2019) 022049. Doi:10.1088/1755-1315/237/2/022049

Elkady, M.F.; M. F.Hussein and H.M. Atiaa (2015). Preparation of nanoactivated carbon from carbon based material for copper decontamination from wastewater. American Journal of Applied Chemistry; 3(31): 31-37. 
Geetha, K.S. and S.L. Belagali (2013). Removal of heavy metals and dyes using low cost adsorbents from aqueous medium,a review. Journal of environmental science, toxicology and food technology (IOSRJESTFT)., 4 (3): 56-68.

Guo, Y.; H. Zhang ; N. Tao ; Y. Liu ; J. Qi and H.X.Z. Wang (2003). Adsorption of malachite green and iodine on rice husk based porous carbon. Mater Chem Phys., 82:107-115

Helrich, K. (1990). Official methods of analysis, $15^{\text {th }}$ ed. Arlington, USA : Association of Official Agricultural Chemist., (1): 673.

Hu, Z.A. (2018). Application of activated carbon in Water treatment. J. Environ. Eng., 11(9):4-6.

Hua, M.; S. Zhang ; B. Pan ; W. Zhang ; L. Lv and Q. Zhang (2012) Heavy metal removal from water/wastewater by nanosized metal oxides: a review.J Hazard Mater., 211-212(1):317-331.

Husen, A. and K.S Siddiqi (2014) Carbon and fullerene nanomaterials in plants system. J Nanobiotechnology, 12:1-10.

Islam, M.S.; W.S. Choi ; B. Nam ; C. Yoon and H. J. Lee (2017). Needlelike iron oxide and $\mathrm{CaCO} 3$ adsorbents for ultrafast removal of anionic and cationic heavy metal ions. Chem. Eng. J.,307: 208-219

Jung, C. ; J. Heo ; J. Han ; N. Her ; S.J. Lee ; J. Oh ; J. Ryu and Y. Yoon (2013). Hexavalent chromium removal by various adsorbents: powdered activated carbon,chitosan, and single/multiwalled carbon nanotubes. Sep Purif Technol, 106: 63-71.

Kumar, R. and J. Chawla (2014). Removal of Cadmium Ion from Water/Wastewater by Nano-metal Oxides: A Review. Water Qual Expo Health., 5:215-226.

Liu, X.; S. Zhang and B. Pan (2012). Potential of carbon nanotubes in water treatment. In: Recent progress in carbon nanotubes, Book 2, InTech.

Nayl, A. A.; A. Reda Elkhashab; T. El Malah; M. Y. Sobhy; A. E. Mohamed; M. S. Ali and H. M. Ali (2017). Adsorption studies on the removal of COD and BOD from treated sewage using activated carbon prepared from date palm waste. Environ Sci Pollut Res ., 24:22284-22293.

Ordonez, S.; M.A.R. fort and G. del cura (2018).Pore Size Distribution and the Durability of a Porous Limestone. Quarterly Journal of Engineering Geology and Hydrogeology., 30: 221-230.

Rai, P.K.(2009). "Heavy Metal Phytoremediation from Aquatic Ecosystems with Special Reference to Macrophytes," Critical Reviews in Environmental Science and Technology, 39(9): 697-753.

Saleh, M.Y. ; E. Gaber ; H. E. Medhat and H. O. Moustafa (2015). Industrial wastewater treatment improvements using activated carbon. Conference: ICEEESD: International Conference on 
Energy, Ecology, Environment and Sustainable Development At: Miami, USA. https://www.researchgate.net/publication/315552769

Tancredi, N. ; N. Medero ; F. Möller; J. Píriz ; C. Plada and T. Cordero (2004). Phenol adsorption onto powdered and granular activated carbon, prepared from Eucalyptus wood. Journal of Colloid and Interface Science., 279(2): 357-363.

Tsai, W.Y. ; C.Y. Chang and S.L Lee (1998). A low coast adsorbent from agricultural waste corn by zinc activation. Bioresour Technol., 64:211-217

Vohla, C. M. ;H. Kõiv ; J. Bavor ; F. Chazarenc and Ü. Mander (2011). Filter materials for phosphorus removal from wastewater in treatment wetlands-a review. Ecol Eng., 37:70-89

Zhao, X. ; L. Lv ; B. Pan ; W. Zhang ; S. Zhang and Q. Zhang (2011). Polymersupported nanocomposites for environmental application: a review. Chem Eng J., 170(2-3):381-394.

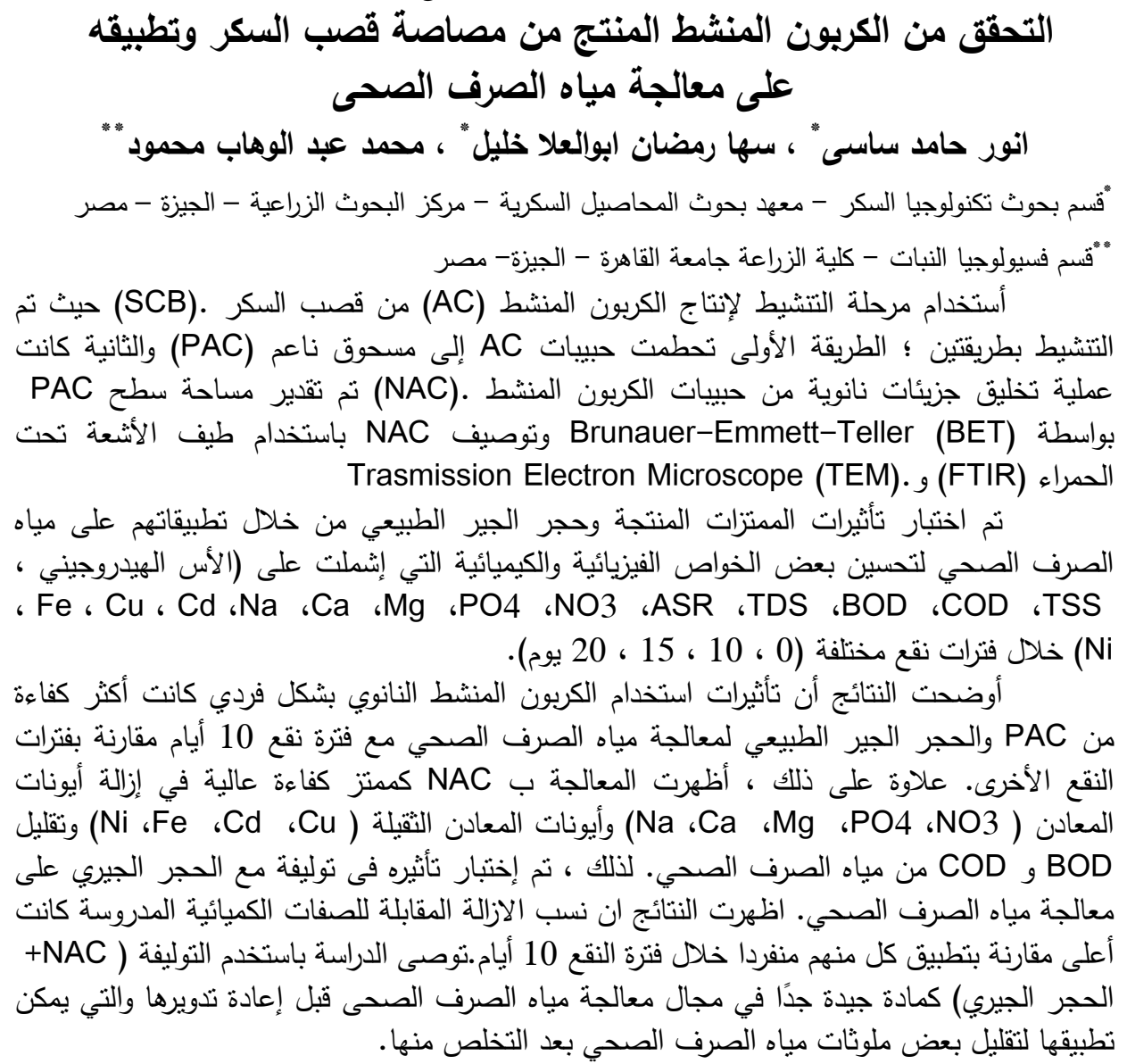

